засуху. Люди попросили Илию о дождичке. И тогда народ понял, что нужно молиться Богам, а не всяким там идолам.

В речи А.М.Захаровой вера в божественную силу проявляется через непроизвольное обращение к Богу, и это явление встречается практически в каждом тексте в качестве устойчивых сочетаний или междометий: «Господи помилуй!», «Боже ты мой!», «Береженова Бог бережет». Таким образом, «связь с сакральной сферой проявлялась на подсознательном, ассоциативном уровне, но сохраняющая даже в виде своеобразного отголоска христианские, православные основы этнического бытия» [6, c.246]. Языковая личность подтверждает тот факт, что мировоззрение сельского жителя представляет собой христианско-языческий синкретизм.

Тексты свидетельствуют о том, что языковая личность информанта является многомерной, в ней воплощены, по сути дела, все уровни, выделяемые исследователями. Мы сделали акцент на когнитивном, мотивационно-прагматическом, эмоциональном и духовном уровнях.

$$
* * *
$$

1. Виноградов, В.В. Личность// Виноградов В.В. История слов/ РАН. Отделение лит-ры и языка: Научный совет «Рус.язык: история и совр.состояние». Ин-т рус.яз. РАН/ отв. ред. Н.Ю.Шведова. М.: Толк 1994. - 416 с.

2. Даль, В.И. Толковый словарь живого великорусского русского языка: В 4 т. Т. 1: А-3 / Владимир Иванович Даль. - М.: Рус.яз. - Медиа, 2006. - LXXXVIII, 699, [9] с., 4 с. ил.

3. Каменская, О.Л. Эмоциональный уровень языковой личности. // Актуальные проблемы теории референции. / О.Л.Каменская. - Сб. науч. статей. Вып. 435. - М.: Изд-во МГЛУ, 1997. - 435 с.

4. Караулов, Ю.Н. Русский язык и языковая личность. / Ю.Н.Караулов. - Изд. 4-е. стереотипное. - М.: Едиториал УРСС. 2004. - 264 с.

5. Кирилина, А.В. Проблемы гендерного подхода в изучении межкультурной коммуникации. А.В.Кирилина. // Гендер как интрига познания: Альманах. Пилотный выпуск. М., 2002, - 78 с.

6. Климкова, Л.А. Слово Бог в русской языковой картине мира. Православие и русская литература. Материалы всероссийской научно-практической конференции «Православие и русская литература. Вузовский и школьный аспект изучения». Арзамас, 22-24 мая 2003 г./ Сост. Б.С.Кондратьев Арзамас, АГПИ, 2004. - 529 с.

7. Лихачев, Д.С.Письма о добром и прекрасном // Сост. и общая ред. Г.А.Дубровской. - 3-е изд. - М.: Дет. Лит., 1989. - 238 с.

8. Ожегов, С.И., Шведова, Н.Ю. Толковый словарь русского языка: 80000 слов и фразеологических выражений / Российская академия наук. Институт русского языка им. В.В.Виноградова. - 4-е изд., дополненное. - М.: ООО «А ТЕМП», 2015. - 896 с.

9. Петрухина, Е.В. Русская языковая картина мира и православное сознание // Виноград: православ. пед. журн. 2007. №3 (19). - С.6-11.

10. Толковый словарь современного русского языка. Языковые изменения конца XX столетия / ИЛИ РАН; под ред. Г.Н.Скляревской. - М.: Астрель: АСТ: Транзиткнига, 2005. - XLVI, 894, [4] с.

11. Щербаков, М.А. Модель уровней самоидентификации личностей. Режим доступа: http:// www.ind.ru/ articles/ ident. Shtml, свободный.

\title{
Ильина В.А. ${ }^{1}$, Драгайцев Д.В. ${ }^{2}$ \\ Характеристика структуры содержания антиценности на примере антиценности болезнь \\ ${ }^{1}$ Российский Новый Университет (РОСНОУ) \\ ${ }^{2}$ Академия социального управления (АCOУ) \\ (Россия, Москва)
}

doi: 10.18411/spc-26-11-2017-07

idsp: 000001:spc-26-11-2017-07

Содержание любой ценности/антиценности может быть овнешнено на разных уровнях сознания и описано в виде текстов и экспериментальных данных. В этой связи отметим, что компоненты ее содержания на уровне общественного сознания описываются на основе анализа дефиниций из энциклопедических источников, на уровне обыденного сознания с опорой на анализ словарных статей из ассоциативного словаря. Компоненты содержания ценности/антиценности на промежуточном уровне 
описываются с опорой на дефиниции в лексикографических источниках, а также пословицы русского языка [Тарасов, 2012]. Проиллюстрируем данное положение примером анализа содержания антиценности болезнь.

В рамках данного анализа первую группу образуют так называемые единичные семы, под которыми мы подразумеваем семы, выделенные только на основе их репрезентации в одном источнике. Примерами являются такие семы, как «речевые синонимы и антонимы», «симптомы болезни», «лечение болезни», «страна, где много болеют», «периоды заболеваемости», «субъекты», «символ болезни», «еда как лекарство», «возраст», «надежда», «нарушение социального функционирования человека».

Во вторую группу входят семы, которые были выделены в двух источниках одновременно. В данной группе выделяются 2 подгруппы. В первую входят родовые и дифференциальные семы, во вторую подгруппу одинаковые семы, выявленные в 2 источниках. Так, например, сема «изменение образа жизни человека» является родовой семой, а сема «последствия болезни» - дифференциальной. Во вторую подгруппу входят такие семы, как «причина», «нарушение или отклонение в жизнедеятельности живых существ», «конкретные заболевания», «разрушение», выявленные в энциклопедических и лексикографических источниках.

В третью группу входят семы, выявленные одновременно в 3 источниках. Так, например, сема «оценка болезни» является родовой семой, а сема «отклонение от нормы в чем-л.», выявленная в энциклопедических и лексикографических источниках, рассматривается как дифференциальная. Сема «расстройство здоровья» - родовая сема, а семы «состояния, связанные с болезнью», «огорчение», «безысходность», «страдание» - дифференциальные. Для наглядности данные группы были помещены в Таблицу 1.

Таблииа 1.

\begin{tabular}{|c|c|c|c|}
\hline $\begin{array}{c}\text { Семантические } \\
\text { компоненты содержания } \\
\text { ценности болезнь в } \\
\text { энциклопедических } \\
\text { источниках }\end{array}$ & $\begin{array}{c}\text { Семантические } \\
\text { компоненты } \\
\text { содержания } \\
\text { антиценности } \\
\text { болезнь в } \\
\text { ассоциативном } \\
\text { словаре }\end{array}$ & $\begin{array}{c}\text { Семантические } \\
\text { компоненты } \\
\text { содержания } \\
\text { антиценности } \\
\text { болезнь в } \\
\text { пословицах } \\
\text { русского языка }\end{array}$ & $\begin{array}{c}\text { Семантические } \\
\text { компоненты содержания } \\
\text { ценности болезнь в } \\
\text { лексикографических } \\
\text { источниках }\end{array}$ \\
\hline- & $\begin{array}{c}\text { Речевые } \\
\text { синонимы и } \\
\text { антонимы }\end{array}$ & P & - \\
\hline- & $\begin{array}{c}\text { Симптомы } \\
\text { болезни }\end{array}$ & - & - \\
\hline- & Лечение болезни & - & _. \\
\hline- & $\begin{array}{c}\text { Страна, где много } \\
\text { болеют }\end{array}$ & - & - \\
\hline & Причины болезни & Причина & _- \\
\hline- & $\begin{array}{c}\text { Периоды } \\
\text { заболеваемости }\end{array}$ & - & - \\
\hline - & Субъекты & _ & - \\
\hline _- & Символ болезни & - & - \\
\hline - & - & Еда как лекарство & - \\
\hline & & Возраст & \\
\hline- & - & Надежда & 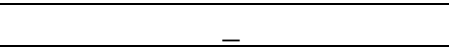 \\
\hline $\begin{array}{c}\text { Нарушение или } \\
\text { отклонение в } \\
\text { жизнедеятельности живых } \\
\text { существ }\end{array}$ & - & - & $\begin{array}{c}\text { Нарушение или отклонение } \\
\text { в жизнедеятельности } \\
\text { живых существ }\end{array}$ \\
\hline $\begin{array}{c}\text { Отклонение от нормы в } \\
\text { чем-л. }\end{array}$ & Оцеенка болезни & - & $\begin{array}{c}\text { Отклонение от нормы в чем- } \\
\text { л. }\end{array}$ \\
\hline
\end{tabular}




\begin{tabular}{|c|c|c|c|}
\hline $\begin{array}{c}\text { Нарушение социального } \\
\text { функционирования человека }\end{array}$ & & - & - \\
\hline $\begin{array}{c}\text { Изменение образа жизни } \\
\text { человека }\end{array}$ & $\begin{array}{c}\text { Последствия } \\
\text { болезни }\end{array}$ & - & - \\
\hline 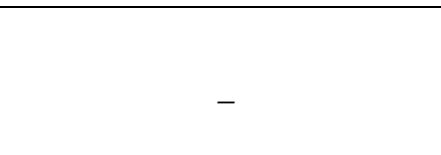 & $\begin{array}{l}\text { Состояния, } \\
\text { связанные с } \\
\text { болезнью }\end{array}$ & $\begin{array}{c}\text { Огорчение } \\
\text { Безысходность } \\
\text { Страдание }\end{array}$ & Расстройство здоровья \\
\hline- & $\begin{array}{l}\text { Конкретные } \\
\text { заболевания }\end{array}$ & - & Конкретное заболевание \\
\hline- & - & Разрушение & $\begin{array}{c}\text { Разрушение, повреждение } \\
\text { чего-л. }\end{array}$ \\
\hline
\end{tabular}

Таким образом, структура содержания антиценности болезнь нам представляется гетерогенной, так как ее компонентами являются семы двух типов: 1) образующие иерархические отношения и 2) не образующие иерархические отношения. Первая группа сем описывает структуру содержания как горизонтально-вертикальную (родовые и дифференциальные семы). В качестве родовых сем выделим следующие три: «оценка болезни», «расстройство здоровья», «изменение образа жизни человека», а также ряд дифференциальных сем («отклонение от нормы в чем-л.», «состояния, связанные с болезнью», «последствия болезни», «огорчение», «безысходность», «страдание»). Вторая группа описывает только горизонтальный уровень структуры, который состоит из единичных сем, не вступающих в иерархические отношения («речевые синонимы и антонимы», «симптомы болезни», «лечение болезни», «страна, где много болеют», «причина» (выявленная в 2 источниках), «периоды заболеваемости», «субъекты», «символ болезни», «нарушение или отклонение в жизнедеятельности живых существ» (выявленная в 2 источниках), «еда как лекарство», «возраст», «надежда», «нарушение социального функционирования человека», «конкретные заболевания» (выявленная в 2 источниках), «разрушение» (выявленная в 2 источниках).

Таким образом, наш анализ содержания антиценности болезнь был проведен на основе четырех источников, соответственно, были выявлены четыре группы семантических компонентов как его результат. Сопоставив полученные результаты, мы охарактеризовали содержание ценности как единое семантическое пространство, в котором компоненты сформировали разноуровневую структуру, так как выявление родовых и дифференциальных сем позволило нам описать структуру содержания антиценности как горизонтально- вертикальную, так как были описаны как семы, вступающие в иерархические связи, так и единичные семы.

$$
\text { *** }
$$

1. Тарасов Е.Ф. Проблема анализа содержания общечеловеческих ценностей // Вопросы психолингвистики. М.: Институт языкознания РАН, 2012. № 1(15). С. 8-17.

\section{Кабирова Ю.И., Баскакова Е.С.}

Особенности перевода безэквивалентной лексики в произведении Н. В. Гоголя «Мертвые души» с русского языка на английский язык

Сургутский государственный университет (Россия, Сургут)

doi: 10.18411/spc-26-11-2017-08

idsp: 000001:spc-26-11-2017-08

\section{Аннотация}

Статья посвящена изучению особенностей функционирования безэквивалентной лексики в произведении Н. В. Гоголя «Мертвые души» на русском и английском 